Georgia State University

ScholarWorks @ Georgia State University

8-2-2019

\title{
Measuring the Quality of Workplace Relations and Organizational Performance with Alternative Balanced Scorecards from Strategic HRM and Employment-Industrial Relations
}

\author{
Bruce E. Kaufman \\ Georgia State University, bkaufman@gsu.edu \\ Adrian Wilkinson \\ Griffith University, adrian.wilkinson@griffith.edu.au \\ Michael Barry \\ Griffith University, m.barry@griffith.edu.au \\ Rafael Gomez \\ University of Toronto, ralph.gomez@utoronto.ca
}

Follow this and additional works at: https://scholarworks.gsu.edu/uwrg_workingpapers

\section{Recommended Citation}

Kaufman, Bruce E.; Wilkinson, Adrian; Barry, Michael; and Gomez, Rafael, "Measuring the Quality of Workplace Relations and Organizational Performance with Alternative Balanced Scorecards from Strategic HRM and Employment-Industrial Relations" (2019). UWRG Working Papers. 129.

https://scholarworks.gsu.edu/uwrg_workingpapers/129

This Article is brought to you for free and open access by the Usery Workplace Research Group at ScholarWorks @ Georgia State University. It has been accepted for inclusion in UWRG Working Papers by an authorized administrator of ScholarWorks @ Georgia State University. For more information, please contact scholarworks@gsu.edu. 


\section{W. J. Usery Workplace Research Group Paper Series}

Working Paper 2019-8-2

August 2019

Measuring the Quality of Workplace Relations and Organizational Performance with Alternative Balanced Scorecards from Strategic HRM and Employment-Industrial Relations

Bruce E. Kaufman

Georgia State University

Adrian Wilkinson

Griffith University

Michael Barry

Griffith University

Rafael Gomez

University of Toronto

This paper can be downloaded at: http://uwrg.gsu.edu

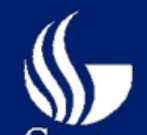

GeorgaState University.

ANDREW YOUNG SCHOOL 


\section{Measuring the Quality of Workplace Relations and Organizational Performance with Alternative Balanced Scorecards from Strategic HRM and Employment-Industrial Relations}

Prof. Bruce E. Kaufman, Department of Economics, Georgia State University, Atlanta GA 30303 USA (bkaufman@gsu.edu)

Prof. Adrian Wilkinson, Centre for Work, Organization and Wellbeing, Griffith University, Nathan, QLD AUS 4111 (adrian.wilkinson@griffith.edu.au)

Prof. Michael Barry, Dept. or Human Resources \& Employment Relations, Griffith University, Nathan, QLD AUS 4111 (m.barry@griffith.edu.au)

Prof. Rafael Gomez, Centre for Industrial Relations and Human Resources, University of Toronto, Toronto ONT CAN M5S 2E8 (ralph.gomez@utoronto.ca)

Contact Author: Kaufman at bkaufman@gsu.edu

Key Words: Balanced Scorecard, Employment Relationship, High Performance Work System, Industrial Relations, Strategic HRM 
Measuring the Quality of Workplace Relations and Organizational Performance with Alternative Balanced Scorecards from Strategic HRM and Employment-Industrial Relations

\begin{abstract}
This paper uses the popular balanced scorecard from strategic management, and a new survey data set, to empirically measure and evaluate the state of workplace employment capabilities, relations, practices, and performance for shareholders and stakeholders. An innovative feature is that two alternative scorecards are constructed based, respectively, on the high-performance work system (HPWS) model and model of an employment relations system (ERS). The two models are depicted and compared in diagrams, used as theoretical frameworks to build alternative scorecards, and filled in with nationally-representative data on more than fifty workplace attributes provided by separate panels of managers and employees from over 2,000 U.S. workplaces. The workplace performance scores are transformed into frequency distributions showing, first, the mean and dispersion of U.S. workplaces as ordered from lowest to highest performance and, second, evidence that the HPWS and ERS models yield different evaluation assessments -- indicating "models matter" for scorecard analysis.

Keywords: Balanced scorecard, Employment Relationship, High-Performance Work System, Industrial Relations, Strategic HRM
\end{abstract}

The balanced scorecard (BSC) concept was introduced in 1992 by Kaplan and Norton (1992) and has become one of the most widely discussed and adopted new management tools of the last thirty years (Sigalas, 2015; Cooper, Ezzamel, and Qu, 2017). The scorecard is designed to provide company executives with real-time information on the internal operation of the organization and progress toward attainment of strategic performance goals so they can early-on identify problem areas and make adjustments (Nivens, 2007). A BSC is frequently analogized to the instrument panel in an airplane's cockpit which gives pilots real-time information on the operation of the plane's systems and projected on-time arrival.

The balanced scorecard has received surprisingly small attention in the human resource management (HRM) field, with exception of two pioneering and frequently-cited books The $H R$ Scorecard by Becker, Huselid, and Ulrich (2001) and The Workforce Scorecard (Huselid, Becker, and Beatty, 2005). These books take the generic BSC concept and rework it to fit a 
company's HR function (first book) and non-supervisory workforce (second book). Other than these two books, Walker and McDonald (2001) appear to be the only BSC study in an HRM field journal while several articles in non-HR journals have applied the BSC to employees in public service organizations (Cunningham and Kempling, 2011) and various HR practice areas, such as safety (Mearns and Havold, 2015) and training (Baraldi and Cifalinò, 2015). Neither the two books nor journal articles, however, work out an operational version of a scorecard nor fill it in with company data. Also, all of these studies examine the BSC solely as a tool for management practice and do not consider its potential use as an analytical HR research measurement and evaluation device.

This paper makes contributions in each of these areas. First, after a fifteen-year hiatus since Huselid, Becker and Beatty (2005), the paper picks up and further develops application of a balanced scorecard to HRM. Second, the paper goes the next step and works out an empirical version of an HRM scorecard and fills it in with data collected from over 2,000 organizations in the United States (US) from a new nationally representative survey, State of Workplace Employment Relations Survey (SWERS). The scorecard results provide a unique snapshot estimate of the mean, variance, and low/high tails of the distribution of American workplaces with respect to the quality of employment relations and workforce performance. Third, the paper demonstrates research applications of the balanced scorecard tool, such as utilizing it to form a measure of organizational workforce performance which can then be used as a dependent variable in statistical analyses.

Equal in significance is yet another area of contribution. As Kaplan and Norton $(1992,1996)$ and Huselid, Becker, and Beatty (2005) emphasize, the structural design of a BSC and set of data measures and performance indicators need to be based on an underlying theoretical model. For 
example, the latter authors (p. 68) state, "without developing models that show 'what causes what' throughout the business - we'll end up with a series of unrelated metrics." Often models appear to practitioners as academic playthings without real world consequence and researchers, though convinced of the practical importance of theory and models, have difficulty pointing to examples where their models yield tangibly-important and operationally-relevant 'so what?' implications. The balanced scorecard, however, provides a great example of Kurt Lewin's aphorism "there is nothing so practical as a good theory" or, as framed in this paper, the proposition "models matter." The transparent reason is that different business/HR models lead to different scorecard designs, different sets of input measures and indicators, and different outcome measures and organizational performance evaluations.

Accordingly, this paper illustrates the "models matter" proposition - and advances theory development in the HRM field for its own intrinsic value - by constructing and comparing scorecards based on two alternative workforce/HR models. The first is the high-performance work system (HPWS) model from strategic HRM (SHRM) employed by Huselid, Becker, and Beatty (2005) and the second is a model of an employment relations systems (ERS) from the contiguous field of employment-industrial relations (EIR). Both models are depicted in diagrams, explained with respect to implications for BSC design, used as templates for construction of alternative HPWS and ERS scorecards, filled in with applicable SWERS data, and compared with respect to degree of difference in evaluation scores and indicated areas of strong and weak employment relations and workforce performance. The models differ along a number of dimensions but two areas of particular significance are shareholder versus stakeholder specification and measurement of the organizational performance construct and the substantially different weights assigned to, respectively, HR practices versus employment 
relations as strategic drivers of performance. In this regard, note that the estimated scorecards do not allow or purport to provide a statistical test of one model versus another but, rather, indicate how different models lead to different scorecard structures and performance evaluations.

Since the HPWS model from strategic HRM is well known and developed, it requires relatively brief explanation. No representation of the ERS model suitable for building a balanced scorecard is available from the employment-industrial relations literature, however, so a section of this paper is devoted to constructing a diagrammatic version. This exercise likewise has intrinsic value for theory development in HRM not only because it provides the field with an alternative paradigm perspective but also demonstrates how this perspective can be transposed into a practitioner-useful measurement tool.

\section{HPWS Workforce Scorecard: Review}

Kaplan and Norton (1996) present a generic four-tier framework for constructing a balanced scorecard. The four levels are a sequence of top-to-bottom business processes - financial, customers, internal business processes, and learning and growth - around which the BSC's basic structure is organized and illustrated in a strategy map diagram. However, a notable paradox and shortcoming of their framework is that each of the four tiers are important drivers of business success but conspicuously missing are employees, human capital, and HRM.

Becker, Huselid, and Ulrich (2001) and Huselid, Becker, and Beatty (2005) correct this shortcoming with The HR Scorecard and The Workforce Scorecard books. They begin both books by also citing a paradox. It is that many companies claim employees are their most valued asset yet in practice give the workforce relatively low strategic emphasis and small investment, particularly with respect to the HR function. The major explanation they give for HR/workforce 
under-investment is "HR's influence on firm performance is difficult to measure" (Becker, Huselid, and Ulrich: 1, emphasis added). Measurement is difficult because many aspects of employees' capabilities and performance are intangible, such as motivation, knowledge, and teamwork. For this reason, Becker, Huselid, and Becker (2001:4) argue, "In our view, the most potent action HR managers can take to ensure their strategic contribution is to develop a measurement system that convincingly showcases HR's impact on business performance." Following Kaplan and Norton, these authors also emphasize that a good measurement system needs to be built on a sound theoretical-representational framework (earlier quotation) and thus they turn to the high-performance work system (HPWS) model.

Shown in the top part of Figure 1 is the scorecard template/strategy map presented by Huselid, Becker, and Beatty (p. 7) for building a workforce BSC. It progresses from lower left (Kaplan and Norton's bottom fourth tier) to upper right (their first tier). The template begins with the departmental HR function, because it is "the foundation of workforce success" (Huselid, Becker and Beatty, 2005: 5). The function's three driver variables are, respectively, HR Management Systems, HR Practices, and HR Workforce Competencies, which jointly determine the function's output called HR Success. HR Success contributes to Workforce Success, defined as (ibid., p. 6): "how well the workforce has contributed to the execution of the firm's strategy." Workforce Success leads to Operational Success, Customer Success, and, as the scorecard's last step, Financial Success. Financial success is a shareholder performance criterion.

It is surprising, given their insistence that a BSC's template and set of measures be guided by an underlying representation of the business and HRM process, that Huselid, Becker, and Beatty (2005) only heuristically describe the HPWS model and provide no formal depiction. In an article several years earlier, however, Becker and Huselid (1998) present an HPWS diagram 
model, reproduced in the bottom part of Figure 1, and relate it to the balanced scorecards subsequently published in the two books. Therefore, we use the combination of the two diagrams in Figure 1 as the HPWS scorecard framework.

Analytically, the firm in the HPWS model is an input-transformation-output model (pictured in Wright and McMahan, 1992). The model (the lower part of Figure 1) goes from left to right and starts in the first box with business and strategic initiatives, with the internal-focused RBV as the main component. The central driver of the model is in the second box with an HRM system of vertically and horizontally aligned high-performance work practices (HPWPs). It corresponds to the HR Management Systems and HR Practices boxes in the template diagram. No consensus has formed on the definition and specification of HPWPs (Wright and Ulrich, 2017) but, typically, the four practices of careful selection, considerable training, performance-based compensation, and careful performance management are universal core elements. The last three boxes in the B\&H representation of the HPWS model are ascending organizational performance outcomes which match the similar three performance success boxes in the template diagram (operational, customer, financial). The steps connecting HRM practices to organizational outcomes in the Becker and Huselid (1998) model approximate the now-standard AMO (ability, motivation, opportunity) model in the third from which come improved employee/HR outcomes in the fourth box.

Becker and Huselid's (1998) HPWS diagram is largely a closed-system model since it has no way to acquire inputs from outside the firm (e.g., hiring in labour markets) or obtain revenue by selling output in product markets to external customers. Their model also lacks relational constructs, such as psychological contract, social exchange theory, and organizational justice, 
and also relational behaviors, such as between managers and employees and within work groups. ${ }^{1}$ Their representation of the HPWS model and template is substantially universalist.

\section{[Insert Figure 1 here]}

Besides grounding their workforce scorecard on the HPWS model, Huselid, Becker, and Beatty (2005) also follow Kaplan and Norton (1996) and define the organizational performance criterion solely in terms of shareholder/management interests in higher operational and financial outcomes. They say, for example, "we define workforce success primarily in terms of successfully achieving business goals" (p. 2) and instruct managers that the firm's relationship with its employees should be a top-down decision governed by "the choices that you believe are essential for... effective execution of your firm's strategy" (pp. 178-80). Also illustrative of a shareholder perspective, and an instrumental resource/input view of employees, Huselid, Becker, and Beatty declare (p. 16, emphasis added), "Strategically relevant workforce success needs to be diagnosed and exploited like any other strategic opportunity or any other asset." Thus, successful strategy execution is managing workforce means to optimally achieve business ends. Reflective of this management-driven perspective, but seemingly contra the emphasis in the HPWS on opportunity for employee empowerment and voice, no provision is made for employee input and participation in the process of scorecard design, implementation, or evaluation.

It is essential to keep in mind that a BSC is a performance measurement tool, similar to a doctor's physical exam worksheet. Its purpose is to signal top management, not predict or

\footnotetext{
${ }^{1}$ The phrase "managing and measuring relationships" in the lower-right box of the BSC template diagram refers in the text to relationships between customers, line managers, and HR managers. Social exchange is included in more recent versions of the HPWS (e.g., Jiang and Li, 2019) but other relational constructs, such as organizational justice, considerably less often.
} 
explain, how well (or poorly) the organization and subunits are functioning, externally/internally aligned, and on track to achieve performance objectives, much as various lab tests and physical measurements indicate to a doctor the performance level/alignment of vital bodily organs and functions and a person's overall state of health. Also, since a BSC is typically operationalized with available measures and data from a firm's accounting, finance, HRM, and operations systems, academic research and methodology issues, such as definition/measurement of HPWPs and specification of AMO causal connections, are much less relevant. Illustratively, Huselid, Becker, and Beatty (2005: 113-14, 72) provide practitioner readers with ninety-six alternative measures of HPWPs and fifty-six measures of workforce success.

\section{Employment Relations Model and BSC Strategy Map}

Both the human resource management and employment-industrial relations fields have their roots as formal areas of research, teaching, and practice in the U.S. in the late-1910s and, to significant degree, were long regarded as overlapping but distinct approaches to workforce management and governance (Dulebohn, Ferris, and Stodd, 1995; Kaufman, 2014). The HPWS and ERS models and scorecards presented here are thus representative of a century-long tradition grounded in partially complementary, partially opposed paradigm visions (Townsend and Wilkinson, 2014).

The workforce scorecard of Huselid, Becker, and Beatty (2005) is built on a managerialist framework of shareholder governance, an internal organizational system substantially closed from the external environment, a universalist/weak-contingent cause-effect structure, and an aligned set of advanced $H R$ practices as the main performance driver. ${ }^{2}$ The ERS scorecard, on

\footnotetext{
${ }^{2}$ Weak contingency means a variable modifies but does not reverse the main effect while strong contingency means at some point it reverses the main effect (Kaufman, 2010).
} 
the other hand, is based on a paradigm having a political economy superstructure with an embedded employment relations system featuring stakeholder governance, an internal organizational system open to the external environment, a strongly-contingent/multiconfigurational cause-effect structure, and positively energized workplace relations as the central performance driver. These features are depicted in the model of an employment relations system illustrated in Figure 2, a new construction combining elements from King (1918), Kaufman (2004), and XXXX (). If “models matter," it will be indicated by divergent performance evaluation estimates generated by HPWS (Figure 1) and ERS (Figure 2) scorecards.

\section{[Insert Figure 2 here]}

The causal direction of order in the ERS diagram goes from top to bottom. At the top of the ERS are three descending levels of external governance. The Nation State is at the apex. The leaders and political-military institutions of the state possess ultimate sovereign power and thus through executive, legislative, and judicial decisions determine the underlying structural type of economy and employment system, such as a free-market neoliberal, social-market coordinated, and socialist centrally-planned (Wilkinson, Wood, and Deeg, 2014: Chs. 4-11). The box under it, labeled National Context, contains four categories -- socio-cultural, legal, institutional, and economic development stage - which contribute more structural differentiation and contextual contingencies within and across countries. The second box, marked Employment Relation Institutions, contains four external influences on firm/workforce governance arrangements: employers' associations, employment-labour laws, trade unions, and NGOs.

All three tiers of external institutions and governance substantively drop out of a (mostly) universalist SHRM-HPWS model, such as in Figure 1. Thus, as an illustration, a multinational 
company could use the same general BSC design, perhaps with selective second-order contextual adjustments, in countries with marked institutional differences across all three tiers of governance. The EIR paradigm perspective, on the other hand, posits that 'context strongly matters' (Barry and Wilkinson, 2011; Brewster and Mayrhofer, 2012). Thus, an American-type HPWS may not be compatible with stage of economic development, national ERS institutions, or socio-cultural norms (e.g., Zimbabwe, Russia, Sweden).

Another part of the external environment is markets. The employment relationship is formed in the labour market (omitted from Figure 1), positioned to the left of the firm (firm = pyramidtopped rectangle) in Figure 2. Demand/supply set an average wage $\mathrm{W}$ within a range of $\mathrm{W}_{\mathrm{MAX}}$ and $\mathrm{W}_{\mathrm{MIN}}$ and firms can strategically position their pay/benefits at a point high, middle, or low (low $\approx$ non-HPWS), and also use RBV techniques to immobilize workers and pay them less (Molloy and Barney, 2015). The two questions are: first, can the SHRM-HPWS model adequately explain this strategic choice, and corollary turnover, work effort, and employee relations effects, with labour markets omitted from the model and, second, if not then is this omission serious enough to create a misleading scorecard tool?

Similarly, the intensity of competition and frequency/size of shifts in demand/supply in both labour and product markets (right of the firm) also exert significant influence on ERS structure and operation. In product markets with homogeneous goods, firms have to follow the market price $\mathrm{P}$ and focus on a cost-reduction strategy while in markets with differentiated goods they have greater ability to set prices and pursue a quality strategy with $\mathrm{P}_{\text {MAX. }}$. Each strategy implies a different mix of internal-development vs. external-market ERS configurations and practices, again at odds with the substantially universalist HPWS model. 
The ERS representation of the firm is broadened, pluralized, and made less determinate by embedding the core input-output function in an organization-level governance structure containing an employment relationship (Simon, 1951; Marsden, 1999; Budd, 2004). This conception of the firm is illustrated by the house-shaped structure in Figure 2. The bottom rectangle contains the production-labour process and input-output function. It proceeds from left to right with physical capital (K), labour (L), and natural resources $(\mathrm{N})$ going into the production process in the middle which yields output (Q) for sale in the product market. The labour/human resource input typically comes from employees, broadly defined to include salaried managers.

The HPWS model in the lower part of Figure 1 not only lacks an external supply source for acquiring new employees to keep the production process running (and, ironically, reason to have an employee selection practice), but also a place in it for existing employees as whole, agentic people (instead of partitioned into KSAs and motivation, with emotions and social-based behaviors mostly omitted). This narrow, compartmentalized approach largely omits, for example, a fuller range of employee needs, interests, and aspirations which in some cases inhibits positivedirected motivation (e.g., an abrasive, insensitive boss) while in others turns motivation toward negative conflict and hostility (e.g., breaching a no-layoff promise) - a behavioral path altogether missing in Figure 1. In the ERS diagram, the firm acquires employees from labour markets and employees qua human agents initiate independent action in pursuit of individual work-related goals, indicated by putting the person figure at the center of the production process and allowing for relational parts of motivation and conflictual, negative-directed behaviors.

At the end of the production process emerges the completed good or service, denoted by the arrow pointing to output (Q). The HPWS model assumes a positive but perhaps contingently modified main effect of HPWPs on output but in the ERS model the main effect is less 
predictable and, if relations and attitudes are sufficiently deteriorated, may be close to zero or turned negative by contingent factors. Therefore, the input-output relationship has considerable plasticity with large variation in observed productivity (Q/L) across firms (Syverson, 2011).

The upper triangle in Figure 2 is the hierarchical management/administrative part of the firm. The CEO is at the top (denoted by another person figure), ranks of management descend to firstlevel supervisor, and the functional HR department (if any) is located in the box. The firm is a governance structure because the employer at top has legal right, subject to legislative and collective bargaining restrictions, to structure and operate the firm, establish and administer labour policies and HR practices, and decide on the distribution of profit/loss. The employment relationship is distinguished by the horizontal line with non-supervisory employees in the rectangle and owner-employer and managerial agents (supervisory employees) in the triangle. To the degree a firm has a 'we versus them' culture, it forms around this line (absent in the HPWS model).

Also different between HPWS and ERS models and scorecards is that the former omits most or all of the organization's management (triangle), particularly above front-line level, as a human resource and performance contributor - and blocker -- while the latter includes it. Huselid, Becker, and Beatty's Workforce Scorecard book, and most HPWS models (see Jiang and Li, 2019), implicitly or explicitly include only (or mostly) non-supervisory employees in the rectangle because of the managerialist assumption they are the 'worker' human resources whose role is to supply labour services by performing assigned job tasks while management's role is to stand above the production process in the triangle and control/coordinate it, partly by monitoring BSC signals of the system's performance and making as-needed adjustments to the HPWP levers. It is also assumed that managers adjust the levers to optimize firm performance but, in 
fact, their defensive resistance to sharing power, decision-making, and information is a major reason for limited HPWS uptake and survival (Lawler, 1986; Beer, 2009).

Employment-industrial relations takes the broad view that everyone in the firm from CEO to door guard is an employee if hired from a labour market on an employment contract. Since executives-managers are often the strategic part of a firm's human capital pool, omitting them from the HPWS model, and also from performance evaluation in a scorecard, seems paradoxically limiting and one-sided (Bloom, Genakos, Sadum, and Van Reenen, 2012). At a micro level it also seems problematic since a widely-reported finding is that the \#1 cause of employee dissatisfaction, low morale, and turnover is a bad boss (Zenger and Folkman, 2012). In a small firm, the ER is typically a dyad with owner-manager in the role of employer and the other people in the role of hourly-wage employees. In a large corporation, on the other hand, the employment relationship expands to a triad with the employer role legally invested in the board of directors who represent the owner/shareholders, the enacted employer role performed by the firm's management hired to serve as the owners' agent, and the non-managerial part of the workforce as employees. These three parties to the employment relation are depicted in Figure 2 by the three overlapping circles inside the firm (King, 1918: Chart 8). The overlapping areas represent common interests among the stakeholders and the non-overlapping areas represent divergent interests. The three circles reduce to the two of employer and employee(s) if owners and managers are treated as a unitary group (no agency problem). A fourth circle could be inserted for an external stakeholder, such as the community, society or future generation, with additional measures added to a BSC. 
A complete merging of the three circles into one represents the ideal of perfect unitarism; that is, everyone in the firm (or nation) acts as an identically motivated and aligned agent working in unison to achieve a common goal (Heery, 2016). Achieving unity of interest in the firm, often framed as getting employees to 'think like owners,' has been a two-century quest of employers and management theorists (Kaufman, 2003; Rousseau and Shperling, 2003). Employmentindustrial relations believes that by their nature employment relationships contain inherent conflict of interests which can never be completely eliminated but, nonetheless, it is a worthy goal to foster greater common interests and thereby greater cooperation, goal alignment, and team spirit. To do so, a necessary condition is stakeholder governance in which pluralist interests are openly recognized and respected, employees are treated as organizational team members with a right to voice, due process, and reasonable security, and interest integration is accomplished through mutualist positive-sum methods (Budd, Gomez, and Meltz, 2004; Beer, 2009).

The SHRM-HPWS approach to unitarism, on the other hand, is critically flawed and prone to yield a mediocre-to-low-performance result. The reason is its humanist, mutual-gain rhetoric is contradictory to its logic and operation. A reading of the Workforce Scorecard book and SHRM review articles (e.g., Lepak, et al., 2006; Wright and Ulrich, 2017), for example, reveals that HRM practices are meant to secure employees' commitment to advancing the firm's wellbeing but the reverse side of the psychological contract - the firm's ongoing commitment to the employees' wellbeing - is little discussed and made questionable by SHRM's emphasis on maintaining organizational flexibility and optimizing financial performance goals. Similarly, common interests are promoted by sharing the rents from hard work and cooperation but the RBV strategy in SHRM is instead to capture most of the rents for the firm by using HRM practices to immobilize employees (Molloy and Barney, 2015; Delery and Roumpi, 2017). 
EIR researchers have studied for a century how to build and sustain a high-performance organization (King, 1918; Commons, 1919; Foulkes, 1980; Kochan and Osterman, 1994; Appelbaum, et al., 2000). In a nutshell, the road to success is not through advanced HR practices and HR function - although they can play an important support role in certain contexts up to a certain point - but with a credible, continually enacted top-level management commitment to a psychological contract of mutual stewardship in which they operate the organization as one big team to achieve an inspiring vision of customer service and firm success with employees treated as valued, resected human beings and longer-term stakeholders/investors provided with good jobs, skill/career development, fair treatment, and voice with reciprocal expectation employees individually and collectively give their full hearts, minds, and bodies to enterprise success (King, 1918:101-02; Commons, 1919: 21-25). Huselid, Becker and Beatty (2005) argue a major benefit of a BSC is to highlight and help quantify the intangible value of investments in the HR function and HPWPs. From an EIR perspective, a still-larger benefit is to highlight and better measure the intangible role and value of, respectively, relations and esprit d'corps as performance drivers and the role and effect of senior management's leadership, business decisions, and employee-HR commitments and actions as drivers of relations and climate. ${ }^{3}$

The ERS representation of an employment relations system in Figure 2 is completed by the two remaining components in the lower part of the diagram. Below the firm is a box titled Competing Social Interests, Values, and Welfare Objectives. It is another part of ERS governance, applicable at both the nation-state and individual firm level. The stakeholders in the ERS, through a social choice process involving various elements of legal mandate, owner-

\footnotetext{
${ }^{3}$ Nearly 90 percent of U.S. firms have less than twenty employees. The ERS model with emphasis on positive relations and attitudes appears better able to explain high performance in this segment than the HPWS model with its emphasis on a strategic HR function and investment in a system of advanced HRM practices
} 
manager decision, joint determination with unions, explicit/implicit negotiation, tacit/overt struggle, and appeal to social norms and ethics, have to answer the fundamental question of whose interests count in how the firm is run and who gets the benefits and bears the costs (Samuels and Schmid, 1981; Budd, 2004; Boxall and Purcell, 2016).

The issue of shareholder vs. stakeholder governance is resolved at this step. Also resolved are other important ERS issues, such as priority to long-term growth versus short-term financial gain, degree of influence and voice given employees, commitment to corporate social responsibility, and policy toward unions and social movement groups. When a firm is embedded in, say, a European-type social-democratic, coordinated social market context, the weight given to employee interests is predictably larger than for a firm in an Anglo-American-type neoliberal, financialized, free-market context. An incongruity in the American HPWS story, therefore, is it requires large, longer-term investment and rent-sharing to get committed, engaged employees but is embedded in a legal-socio-economic system which pushes firms in the opposite direction.

The 'whose interests count' question has other important implications. For example, the purpose of SHRM theory is to predict and explain organizational performance and, similarly, the purpose of a balanced scorecard is to provide company leaders with a dashboard of signals on the state of performance. However, the definition and measurement of organizational performance, and what constitutes a means vs. end in optimizing performance, is indeterminate without a prior answer to whose interests count. If only shareholders' interests count, a BSC will contain one set of measures and indicators of input, process, and outcome performance, ending with final-state goals such as efficiency, profit and ROI (Budd, 2004; Boxall and Purcell, 2016). On the other hand, if interests of owners, management, and employees all count, or if social and humanistic 
objectives are included, a BSC contains a different set of internal indicators and performance measure, such as facets of employee and community development and wellbeing.

The last part of the ERS model is the frequency distribution, labeled $\mathrm{ER}_{1}$, at the bottom part of the diagram (adapted from Kaufman, 2014). It plots from left to right the organizational performance achieved by a cross-section of companies, such as measured by a BSC (the empirical section that follows). A large contingency, however, is that choice of governance form, such as shareholder vs. stakeholder, substantially changes how performance is defined and measured and results in different frequency distributions and scorecard evaluations.

The left endpoint of the performance (PERF) measurement scale is anchored by the firm with the worst workforce/employment relations (ER) performance score and on the right by the firm with the best. A scientific-analytical purpose of theory is to predict the likely shape of the PERF distribution for a group of companies, where an individual company is likely located in the distribution, and how the distribution changes shape and position in response to different contextual/contingent factors. The HPWS model, for example, predicts (ceteris paribus) that over time the distribution shifts rightward with growing compression at the upper end as firms increase HPWP usage (a 'race to the top') while a radical-Marxist model (Kelly, 1998) predicts the opposite with ongoing leftward shifts as capitalist employment relations cumulatively worsen (a 'race to the bottom').

The ERS model, reflecting its vision of a low-high continuum of relations (Budd and Bhave, 2008; Kaufman and Miller, 2011; Heery, 2016), predicts a relatively dispersed distribution, possibly more or less bell-shaped. A prediction, for example, is the distribution is more dispersed in individualistic/neoliberal countries (Katz and Wailes, 2014) because of a less regulation, 
unionism, and social constraints (top of ERS diagram). Also, the distribution is predicted to shift rightward and leftward with economic cycles (leftward in recession/depression) and political/social developments (rightward with less class polarization/conflict). In the long run, the ER distribution slowly shifts rightward with improvements in technology, education, businessmanagement methods, work-living conditions, and shared growth-prosperity.

A possible outcome is that firms in different ERS contextual-configurational groups, such as control vs. commitment or externalized vs. internalized, cluster at different points along the distribution if their group performance is moderated by a contextual variable, such as degree of product market competition/turbulence or knowledge/talent intensity of the product. It cannot be automatically inferred, therefore, that a firm lower in the distribution is less efficient and, even if less efficient, the immediate response is not 'more HPWPs' but, instead, to use the BSC to locate the under-performing area and then take targeted action.

\section{ERS Report Card: Structure, Questions, and Scores}

This section of the paper shifts to empirical construction and estimation of balanced workforce scorecards using data covering more than 2000 American workplaces from the new State of the Employment Relation Survey (SWERS, 2016). The analysis proceeds in two steps. First, the ERS model in Figure 2 is used to create an illustrative ERS workforce scorecard. Because a major objective of the paper is to use alternative scorecard structures and performance estimates as a comparative device to illustrate and evaluate the 'do models matter?' question, the second step of the empirical analysis is to construct a representative version of Huselid, Becker and Beatty's (2005) HPWS scorecard and compare its performance scores with those from the EIR scorecard. 
External funding allowed the authors to engage a survey company to help design and implement SWERS so it is nationally representative and has separate (non-matched) employer and employee panels. The employer respondents were upper-level executives and managers, screened to omit people who managed ten or less employees or reported small knowledge of company employee relations and HR practices. Employee respondents had to be 18 years or older and working at least 20 hours a week and screened to omit people who reported managerial or supervisory responsibility. Minimum workplace employment size was 20 people.

The employer and employee surveys were answered online by people selected by the survey company from a large panel of pre-assembled respondents using a quota sampling method. Categories of important respondent characteristics are stipulated, such as age, gender, industry, occupation, and union status, and people in the overall panel with a specific characteristic are invited to participate until the required number within and across categories are obtained to ensure national representativeness (subsequently checked against government-reported data).

The employer questions were framed at the company, business unit, or facility level with respondents instructed to pick the highest level for which they had reasonable knowledge; also, managers were instructed to answer more detailed questions on employee attitudes and behaviors and employment-HR practices for the largest, most representative employee group. Employee questions were typically framed at the workplace level but with respondents instructed to answer for a smaller segment if needed for accurate answers, such as a department or work unit. Some non-comparability between employer and employee responses is thus introduced, since the answers from managers typically cover a larger and perhaps different workforce segment relative to the answers from employees, but it was deemed more important for reliable results that employees answer for only the workgroup size for which they have reasonable knowledge. 
The questions for the surveys were jointly developed with the survey company. The authors provided a list of research issues, topics, and sample questions and the company, based on previous workplace surveys and a substantial inventory of pre-tested questions, returned a draft questionnaire which then was revised in a multi-step iterative process until both sides signed off. The upper limit on questions was approximately ninety which had to be diversified to cover several different research topics. The surveys were pre-tested in late 2015 and final results collected by late January 2016. The survey was completed online by approximately 2000 employees (roughly one-third more than minimum required for representativeness) and 500 managers, with extra panel members randomly selected to answer the pre-test version.

The structure, measures, and data for the scorecard are shown in Table 1. The first six columns are from the employer (manager) survey and the last six are from the employee survey. For both employers and employees, the first two columns report mean scores/grades for the entire samples and the last four columns report, respectively, scores/grades for the companies whose mean scores are in the bottom $20 \%$ and top $20 \%$ of the distributions. Median scores were calculated but seldom differed much from the means and are not reported.

\section{[Insert Table 1 here]}

The answers to nearly all the questions in the survey were solicited on a 1-7 scale with $1=$ lowest/worst and $7=$ highest/best. To facilitate interpretation, the numerical scores were converted into letter grades on a F to A scale, with grades above D also separated into minus and plus categories. The conversion scale is made as symmetric as possible: $1.0-2.49=\mathrm{F} ; 2.5-3.49$ $=\mathrm{D} ; 3.50-4.49=\mathrm{C} ; 4.5-5.49=\mathrm{B} ;$ and $5.5-7.0=\mathrm{A}$. In-between letter grades are defined using 
the same symmetric approach (e.g., C- $=3.5-3.83 ; \mathrm{C}=3.84-4.26$; and $\mathrm{C}+=4.17-4.49$ ). Negatively-framed questions are inverted to match the 1-7 scale.

The ERS model in Figure 2 guided construction of the scorecard and choice of fifty measures from SWERS. The framework backbone, similar to the HPWS model, is a set of measures that parallel the inputs $\rightarrow$ production process $\rightarrow$ outcomes sequence. The ERS scorecard is then differentiated from the HPWS scorecard by three distinctive model features. The first is shifting from shareholder to stakeholder governance; the second is defining 'employee' broadly to include both management and production-operations workers, and the third is to monitor not only the efficiency with which employees are used as human resource inputs but also the pulse and tenor of the performative and affective relations across and between all employees (broadly defined) and levels of the organization, including interpersonal relations, group social relations, and organizational climate and morale. For Table 1 the aim is to have maximum comparability of responses by managers and employees, respectively, so with only a few exceptions the scorecard is constructed using directly comparable questions asked in both manager and employee panels. For comparison of ERS and HPWS scorecards in the next section a different strategy is required.

Incorporating these features creates a workforce scorecard with ten sections (see Table 1). Sections 1, 2, and 9 contain separate stakeholder outcome measures for, respectively, companies/managers, operational employees, and community/public. (Owners and managers are treated as a unitary interest group since it was impossible to survey owners/stockholders.) Because the labour input factor is defined broadly in the EIR model to include both the management and non-management portions of the workforce, separate input sections to measure the capabilities (KSAs) and performance of both groups are included as Sections 3 and 4. The production process and internal employment system in Figure 2 are coordinated and regulated 
by, respectively, management directive and HRM practices so their quantity, quality, capabilities, and performance are measured in Sections 6 and 7. Finally, central to the EIR model is the relational-social-fairness climate in the organizational and breadth-depth of positive winwin employee relations practices (promoting integration of interests via merging the three circles in Figure 2), as measured in Sections 5 and 8. Thus, the scorecard mirrors the EIR model.

Section 10 reports the overall score/grade, calculated as the average value of the fifty individual measures, and is the scorecard's ER performance variable (PERF in the ER frequency distribution in Figure 2). The averaging process gives each item equal weight.

\section{Results and Findings}

Quite apart from concerns with alternative models, the data in Table 1 provide a great body of new information on workplace/employment relations capabilities, practices, and performance for this cross-section of American workplaces, in certain respects exceeding what is available from the UK's Workplace Employment Relations Survey (WERS; see Brown, Bryson, Forth, and Whitfield 2009). Main findings and patterns are summarized below.

Scanning the fifty indicators reveals that the mean scores from managers cluster in the $\mathrm{B}+$ to Arange and in the $\mathrm{C}$ to $\mathrm{B}$ - range from employees. The fifty indicators are then summed and averaged to get an overall scorecard score and grade for each company which, in turn, are summed and averaged across all companies in the respective SWERS panels to get the grand means, shown in the last row (Section 10) and identified as Overall Scores. Since the SWERS data are constructed to be nationally representative, Table 1 represents a national-level ER/workforce scorecard. The numbers/grades, in turn, show the mean performance level of the workforce/employment relation calculated from the fifty diagnostics reported by, respectively, 
managers (col. 1) and employees (col. 4). The scores/grades are 5.28/B+ from managers and 4.50/B- from employees (the boundary line between C+ and B-).

These findings have a good news/bad news quality but overall seem on the positive side. Good news is that company managers, in the aggregate, rate most aspects of the workforce/employment relation in the $\mathrm{B}+$ to $\mathrm{A}$ - range. Also, given two-three decades of widespread organizational restructuring and downsizing, hollowing out of the industrial sector and loss of middle-class jobs, and economic-social polarization mirrored in stagnant employee real earnings and meteoric rise in executive pay, worse results than a low B- from employees would not have been surprising. But, on the less positive side, a grade of $\mathrm{C}+\mathrm{B}$ - indicates that at least from employees' perspective the average American company falls well short of a highperformance workplace and, among the bottom half, seems to raise a serious question concerning the competitiveness and the quality of workforce performance and company management.

It is also important to look at the distribution of scores/grades around the mean. As a first step, shown in Table 1 are the averages for workplaces located in the bottom $20 \%$ and top $20 \%$ of the respective distributions. The bottom $20 \%$ of firms as rated by managers get a low C-grade while the top $20 \%$ get a high $\mathrm{A}+$ grade; employees give respective grades of $\mathrm{F}$ and $\mathrm{A}$. This analysis reveals that America has a top tier of 'great places to work' that are 'A range' in workforce and employment relations performance, as rated by both employers and employees, but it also has a bottom tier of workplaces rated by managers and employees as bad-to-terrible $(\mathrm{C}-/ \mathrm{F})$. Other than lack of an HR function and HPWP usage, the SHRM-HPWS model cannot explain the low end.

More information on the range and dispersion of workforce/ER scores is provided in Figure 3. It orders from lowest to highest the scorecard grades for every workplace in the respective 
employer and employee panels which creates the two frequency distributions. These distributions are empirical representations of the theoretical PERF frequency distribution at the bottom of Figure 2 and summarize the state (or pulse) of the employment relation in companies across the US. Both employer and employee distributions are roughly bell-shaped but the employee distribution has a distinctly lower mean and dispersion around the mean while the employer distribution has greater skewness in the left-hand tail (from no artifact we can discover). For both practitioners and policy makers these distributions provide a benchmark tool for evaluating strong and weak workforce areas and relative company performance; for researchers they provide a representation of one of the HRM and EIR fields' core outcome dependent variables.

\section{[Insert Figure 3 here]}

Three other aspects of the scorecard findings in Table 1 deserve examination before moving on to the next section and comparison of SHRM and EIR scorecards. First, the data reveal that employers and employees clearly have different perspectives on each other, their relation, the work situation, and performance outcomes (similarly, see Liao, Lepak, Toya, and Hong, 2009). Even though similar questions are used from SWERS, scores are nonetheless not entirely comparable because manager and employee respondents come from different organizations and work group units. Given this limitation, differences in mean scores are large and pervasive. Of the thirty-eight individual indicators spanning employer and employee columns, mean letter grades are the same in zero cases. For twenty-seven indicators the mean score given by employers is at least one letter grade higher than given by the employees and for eleven the gap is larger still. In only five cases are the employers' mean grades lower than employees' 
(company competitive position, low employee turnover, expensive to replace employee group, low conflict/infighting, employees interested in what management, says/does). ${ }^{4}$

An additional use of the scorecard is to identify particularly weak or troublesome performance areas in the ERS. Scanning over sections 1-8 which are internal to the firm, the section with the relatively lowest manager scores is employer-employee relations and climate (sec. 5) while the three lowest scoring areas for employees are management style (sec 6), HRM functional practices (sec 7), and employment practices for mutualism (sec 8). The individual indicators in the scorecard which employees rate very low but managers rate much higher include: quality of people management, $(\mathrm{A}-/ \mathrm{C}+)$, confidence/trust in management (A-/C+), family/partnership feeling (A-/C+), and workplace morale (A-/C+). They deserve attention because all are critical ingredients for a successful HPWS.

\section{HPWS and ERS Scorecards Compared}

In this section SWERS data are used to fill in two different scorecards. One approximates the HPWS-based workforce scorecard (Figure 1) and the second the ERS-based scorecard (Figure 2). One purpose is to see the degree to which 'models matter' for evaluating firm performance.

This exercise faces several large challenges and accompanying limitations so the findings are best considered indicative approximations. First, Huselid, Becker, and Beatty (2005) do not take the very general template diagram at the top of Figure 1 and flesh it out into a more detailed scorecard framework. Second, they do not empirically operationalize a scorecard by filling it in

\footnotetext{
${ }^{4}$ To provide evidence that the difference in mean scores underlying the letter grades across the thirty-eight comparable manager and employee questions is statistically significant, we pooled the two data sets and ran a regression with a dummy variable taking the value of 1 for manager observations. It was statistically significant at the 95 percent confidence level for all thirty-eight variables (positive in thirty-three cases and negative in five).
} 
with data and working through the steps to get outcome scores. Third, recreating their scorecard is limited by the data in SWERS and, in particular, a number of the HPWS-relevant questions specified by Huselid, Becker, and Beatty are only available from the manager data panel (e.g., the respective sections on frontline managers and drivers of HR success; individual questions such as "company has great value proposition").

Given these caveats, following the BSC template, Becker-Huselid (1998) model in Figure 1, and textual discussion in their scorecard book leads to the shareholder-HPWS form of balanced scorecard in the top half of Table 2 (sections 1-8). The bottom part of the table (sections 9-14) then adds elements from the stakeholder-ERS scorecard from Table 1 for illustrative comparison.

[Insert Table 2 here]

The HPWS scorecard is constructed by starting at the top right of the Figure 1 template diagram (company outcomes) and moving down to bottom left (drivers of HR success). Thus, the first three sections of the scorecard are, respectively, Company's Financial Performance, Customer Success, and Operational Success (also corresponding to last three boxes in the Becker-Huselid model). Next in the template is Workforce Success (their model's box 4) which is section 4 in the table. Then follows section 5 on Drivers of Workforce Success (middle of template), subdivided into three subsections for each driver category in the model; section 6 on HR success; and section 7 with the three groups of drivers of HR success (template lower left). The third driver group in section 7 is high-performance HR Practices. It is measured by the mean score of the sixteen HPWPs from SWERS: internal promotion, large training investment, firm-specific training, careful selection, careful performance evaluation, wage level, benefits level, performance-related pay, employment security, voice and involvement, employee teams, 
employee listening/opinion methods, internal communication, formal/fair dispute resolution, advancement opportunities, and flexible work arrangements. The overall workforce score and grade are given in Section 8. Finally, all items in sections 1-7 use data from the employer panel of SWERS for the data availability reason explained above, plus most SHRM studies rely on management-provided data and using it reflects the managerialist cast of SHRM.

Executives looking down the column of thirty grades see only four that are below a B level while the largest group (twenty-four) are A-. As they look for particular problem areas, three stand out: 'employees are connected/interested in what managers say/do' (C-) and front-line managers and production employees 'have few underperformers' (D+/D+). The scorecard is usefully signaling to executives that, first, front-line managers and the HR-directed performance management system are failing to adequately identify and weed-out low performers in the workforce (what Huselid, Becker, and Beatty refer to as 'C-level players') and, second, there is a troublesome communication-engagement gap between upper management and front-line managers and workers. However, these two problem items seem self-contained and otherwise the scorecard indicates the average American firm has fairly impressive performance in the two central categories of Workforce Success (all A-) and HR Success (A- to question 'HR function has strong value-added to the company'). The data indicate that adoption of sixteen HPWPs for these mid-distribution firms is also an impressive $\mathrm{B}+$ level. Finally, the executives reach the bottom of the scorecard and see an overall performance grade of $\mathrm{B}+$ which, for the average firm, seems a quite positive 'medium-high' outcome (the grade rises to A- if the three lowest grades are omitted).

This type of descriptive and evaluative information fills in a large 'blank space' on the state and performance of employment relations, in turn a major determinant of competitive advantage 
across firms and nations and thus of interest to researchers, managers, and policy makers. However, both Kaplan and Norton (1996) and Huselid, Becker, and Beatty (2005) note the GIGO danger (garbage in, garbage out) with a BSC and therefore this is where the issue of 'models matter' comes to the fore.

To see if models matter, added to the scorecard in Table 2 is a stakeholder/EIR portion (sections 9-14). It includes the three distinctive EIR components: employee stakeholder outcomes; capabilities/performance of the top-to-middle part of management; and important workplace relational dimensions. However, to preserve comparability these three parts are repackaged into scorecard sections that match the HPWS template (e.g., Company's Financial Success is transposed to 'Employee Wellbeing Success'). The result is a total of four new sections with thirty-seven mostly non-overlapping diagnostic measures. These measures are filled in with data from the employee panel of SWERS because, first, roughly one-half of the measures in sections 9-14 are either non-comparable or not included in the employer survey; second, part of the difference between HPWS and ERS models is that the latter prioritizes taking into account not only differences in manager-employee interests but also perceptions; and third, it reflects the EIR field's employee/stakeholder value commitment.

Specifically, Employee Wellbeing Success in section 9 is the overall objective and set of interests employees seek to optimize (from section 2 of Table 1). Section 10 on Drivers of Employee Wellbeing Success are organized into three analogous categories paralleling section 5 (drivers of workforce success in HBB's template), except with reversed focus on how managements' KSAs and behaviors drive employee wellbeing. HR Function in section 11 is limited to one measure since it is the only HR-related question in the employee survey part of SWERS. Relations in section 12 is a category entirely missing from HBB's template and the 
B\&H model but is central to the EIR model. It is divided into two categories, Relational Behaviors (most of section 5 in Table 1 scorecard plus additional relational items only in employee survey) and Relational Practices (from sections 6, 8 of Table 1 scorecard).

The executive looking down the column of scores/grades in the bottom half of Table 2 gets a much less optimistic 'pulse of the workplace' report (XXXX). The average grade from the tophalf of Table 2 for the HRM part of the scorecard is $\mathrm{B}+$ but drops a full letter grade to $\mathrm{C}+$ in the bottom-half for the EIR part. Among the thirty-seven individual measures, twenty are in the $\mathrm{C}$ range. The divergence between the shareholder and stakeholder sections of Table 2 is also revealed in Figure 4 which shows their respective frequency distributions. These differences in scores and distributions clearly separate the shareholder top half and stakeholder bottom half, with the former providing a more positive evaluation of workforce/ER performance.

[Insert Figure 4 here]

\section{Implications and Limitations}

The results from Table 2 and shareholder vs. stakeholder portions of the scorecard have a number of limitations and have to be evaluated with caution. The samples of managers and employees in SWERS are from non-matched companies, their answers may apply to different organizational groups of employees, and in part for reasons of data availability the top-half of the scorecard uses the employer panel data and bottom-half uses the employee data. The performance scores from the two scorecards must be considered, therefore, illustrative outerbound approximations of "models matter" since some of variation also reflects differences in organizational level and function of respondents (suggested by broadly similar distributional 
shapes in Figures 3 and 4). With these significant caveats in mind, several patterns and implications are noteworthy.

A major dividing line between the SHRM and EIR models is that the former focuses primarily on the non-supervisory portion of employees while the latter includes both managerial and nonsupervisory groups. The first two parts of section 10 contain a total of eight questions on Management Behaviors and Management Competencies and five of the grades are in the $\mathrm{C}$ range (as evaluated by employees). In effect, the EIR scorecard is a type of 360-degree appraisal instrument with employees given opportunity to rate the upper management team and they get distinctly mediocre ratings on capabilities and behaviors - a strategic performance driver entirely missing from the SHRM scorecard.

A second critical area of difference between SHRM and EIR models is with respect to the role of workplace relations. The relational dimension, such as trust, fairness, and morale, is mostly omitted from the SHRM model and the Table 1 scorecard reveals this dimension gets the lowest section score. The SHRM scorecard, therefore, is likely to give an inflated performance estimate, per the finding in the Table 2 composite scorecard that the SHRM top part yields a workforce performance score of $\mathrm{B}+$ while the EIR score is $\mathrm{C}+$, a significant one-point difference. Use of employer survey data for the relations questions in Table 2 narrows the gap but only partially since, as shown in Table 1, managers also give lowest overall scores to the relational dimension.

A third important implication is that basing a scorecard on a shareholder vs. stakeholder model makes a large difference in results. For executives of a shareholder-driven firm, the beginning and end of a workforce scorecard is section 1, Company's Financial Success, and everything else is relevant only as it instrumentally facilitates posting a 7/A+ score in this one area. Thus, on one 
hand, it is not valid to say that shareholder firms do not care about employees' wellbeing; rather, they pay attention -- perhaps great attention -- but only to the extent it boosts profit/ROI.

Unless these relational attitudes and behaviors have zero influence on Workforce Success, their omission from the HRM model and HPWS scorecard can be faulted as a consequential omission even from a purely shareholder perspective. From a stakeholder perspective, however, the HRM model is incomplete not only because it largely omits relational aspects but even more so because it evaluates workforce success and organizational performance only in terms of final-end owner/organizational interests. However, the scores/grades in section 9, Employee Wellbeing Success, and section 12, Relations, are regarded by these stakeholder executives not only as a means to a profit end but also a business end in their own right. Thus, the board of directors and CEO would look down the columns of predominantly $\mathrm{C}$ grades for employee wellbeing and relations and decide, if profits and financial conditions are minimally sufficient (even the most committed stakeholder firm has to earn a profit) to invest resources in raising them to, say, B or even A grades - partly because employee wellbeing and mutual gain are formal corporate objectives but also conviction that in the long-run it produces better business results.

\section{Summary}

This paper provides a first-time diagrammatic representation and comparison of the highperformance work system (HPWS) model from the field of strategic HRM and employment relations system (ERS) model from the field of employment-industrial relations. The two models are used to construct separate balanced scorecards (BSC); the scorecards are filled in with data from (unmatched) managers and employees on fifty-plus scorecard measures from a crosssection of 2000 US companies; the measures are aggregated to yield an overall performance 
score (1-7 scale) for each company; and the company scores are plotted as a frequency distribution.

Starting with an ERS scorecard, the paper found the average performance score for the 2000 companies, transformed into an A to F scale, calculated from the employee panel is on the border between $\mathrm{C}+$ and $\mathrm{B}-$ while managers in the employer panel give a $\mathrm{B}+$. Although clearly rough performance estimates, these scores and accompanying frequency distributions (with some bellshaped resemblance) provide a unique macro-level picture of the state (pulse) of the employment relation in the US. The good news from these estimates is that managers on average perceive a relatively high level of workforce performance and employment relations and both managers and employees report a significant proportion of firms rate as 'good-to-great' places to work. The bad news is largely the obverse - employees on average give their workplaces and managers relatively mediocre scores and employees (less so managers) report a significant proportion of 'bad-to-terrible' workplaces.

An expanded scorecard is then developed with one part based on the HPWS model and the other on the ERS model. When filled in with data, the HPWS scorecard gives about a one letter grade higher score to workforce/employment relations performance than the ERS scorecard. This result, although not ironclad because of data limitations, provides directional evidence that "models matter" not only at the level of academic research but also at empirical, practice, and policy levels, as revealed in different BSC designs, estimates, and interpretations for a crosssection of 2000+ American companies.

Along with derivation of two alternative balanced scorecards, another significant feature of the paper is a first-time representation and comparison of two alternative paradigm models for 
analyzing the nature of the HRM-performance relationship. A number of critiques of the HPWS model have been published but they have so far had relatively small impact, partly because in the eyes of defenders (e.g., Troth and Guest, 2019) the critics have not provided a better alternative. On one hand, therefore, our main purpose in synthesizing and formalizing in diagram form the ERS model from the employment-industrial relations field is to provide a well-developed theoretical skeleton on which to construct an alternative scorecard. However, since the field has so far lacked an alternative to the HPWS, and because an alternative theory has many other applications across HRM besides a balanced scorecard, we chose to use the scorecard as a vehicle for a modest extra development of the ERS model in order that the contribution of the paper extends beyond this one topic to the field writ large.

\section{References}

Baraldi, S., \& Cifalinò, A. (2015). Delivering training strategies: The balanced scorecard at work. International Journal of Training and Development, 19(3): 178-98.

Barney, J., \& Clark, D. (2007). Resource-Based Theory. New York: Oxford.

Barry, M., \& Wilkinson, A. (2011). Research Handbook of Comparative Employment Relations. Northampton: Elgar.

Becker, B., Huselid, M., \& Ulrich, D. 2001. The HR Scorecard. Boston: Harvard Business School Press.

Becker, B., \& Huselid, M. (1998). High performance work systems and firm performance: a synthesis of research and managerial implications. In G. Ferris (ed.), Research in Personnel and Human Resource Management, 16(1): 53-101.

Beer, M. (2009). High Commitment, High Performance. San Francisco: Jossey-Bass.

Bloom, N., Genakos, C., Sadun, R., \& Van Reenen, J. (2012). Management practices across firms and countries. Academy of Management Perspectives, 26(1): 12-40. 
Boxall, P. (2013). Mutuality in the management of human resources: Assessing the quality of alignment in employment relationships. Human Resource Management Journal, 23(1): 3-17.

Boxall, P., \& Purcell, J. (2016). Strategy and Human Resource Management. London: Palgrave-Macmillan.

Brewster, C., \& Mayrhofer, W. (2012). Handbook of Research on Comparative Human Resource Management. Northampton: Elgar.

Brown, W., Bryson, A., Forth, J., \& Whitfield, K. (2009). The Evolution of the Modern Workplace. Cambridge: Cambridge University Press.

Budd, J. (2004). Employment with a Human Face. Ithaca: Cornell University Press.

Budd, J., \& Bhave, D. (2008). Values, ideologies, and frames of reference in industrial relations. In P. Blyton, N. Bacon, J. Fiorito, and E. Heery (eds), Sage Handbook of Industrial Relations: 69-91. London: Sage.

Budd, J., Meltz, N., \& Gomez, R. (2004). Why a balance is best: the pluralist industrial relations paradigm of balancing competing interests. In B. Kaufman (ed.), Theoretical Perspectives on Work and the Employment Relationship, 195-228. Champaign: IRRA.

Commons, J. (1919). Industrial Goodwill. New York: McGraw-Hill.

Cooper, D., Ezzamel, M., \& Qu, S. (2017). Popularizing a management accounting idea: the case of the balanced scorecard. Contemporary Accounting Research 34(2), 991-1025.

Dulebohn, J., Ferris, G., \& Stodd, J. (1995). The history and evolution of human resource management. In G. Ferris, S. Rosen, and D. Barnum (eds.), Handbook of Human Resource Management:18-41. New York: Blackwell.

Gittell, J., Seidner, R., \& Wimbush, J. (2009). A relational model of how high-performance work systems work. Organization Science, 21(2): 490-506.

Heery, E. (2016). Framing Work. London: Oxford University Press.

Huselid, M., Becker, B., \& Beatty, R. (2005). The Workforce Scorecard. Boston: Harvard Business School Press.

Jiang, K., and Li, P. (2018). Models of strategic human resource management. In A. Wilkinson (ed..), Sage Handbook of Human Resource Management, forthcoming.

Kaplan, R., \& Norton, D. (1992). The balanced scorecard - measures that drive performance. Harvard Business Review, 70(1): 71-79. 
Kaplan, R., \& Norton, D. (1996). The Balanced Scorecard. Boston: Harvard Business School Press.

Katz, H., \& Wailes, N. (2014). Convergence and Divergence in Employment Relations. In A Wilkinson, G. Wood, \& R. Deeg (eds.), Oxford Handbook of Employment Relations, 4261. Oxford: OUP.

Kaufman, B. (2003). The quest for cooperation and unity of interest in industry. In B. Kaufman, R. Beaumont, \& R. Helfgott (eds.), From Industrial Relations to Human Resources and Beyond: The Evolving Process of Employee Relations Management: 115-46. Armonk: M.E. Sharpe.

Kaufman, B. (2004). Employment relations and the employment relations system: A guide to theorizing. In B. Kaufman (Ed.), Theoretical Perspectives on Work and the Employment Relationship: 41-76. Urbana-Champaign: LERA.

Kaufman, B. (2010). SHRM theory in the post-Huselid era: Why it is fundamentally misspecified. Industrial Relations, 49(2): 286-313.

Kaufman, B. (2014). Explaining breadth and depth of employee voice across firms: a voice factor demand model. Journal of Labor Research, 35(3): 296-319.

Kaufman, B. (2015). Market competition, HRM, and firm performance: the conventional paradigm critiqued and reformulated. Human Resource Management Review, 25(1): $107-25$.

Kelly, J. (1998). Rethinking Industrial Relations. London: Routledge.

King, W. (1918). Industry and Humanity. Toronto: University of Toronto Press.

Kochan, T., \& Osterman, P. (1994). The Mutual-Gains Enterprise. Cambridge: HBS Press.

Laio, H., Lepak, D., Toya, K., \& Hong, Y. (2009). Do they see eye to eye? Management and employee perspectives. Journal of Applied Psychology, 94(2): 371-91.

Marsden, D. (1999). A Theory of Employment Systems. Oxford: Oxford University Press.

Mearns, K., \& Håvold, J. (2003). Occupational safety and health and the balanced scorecard. TQM Magazine, 15(6): 408-23.

Molloy, J., \& Barney, J. (2015). Who captures the value created with human capital? A marketbased view. Academy of Management Perspectives, 29(3): 309-25.

Nivens, P. (2007). Balanced Scorecard Step-by-Step, $2^{\text {nd }}$ ed. New York: Wiley. 
Rousseau, D., \& Shperling, Z. (2003). Pieces of the action: ownership and the changing employment relationship. Academy of Management Review, 28(4): 553-70.

Samuels, W., \& Schmid, A. (1981). Institutional Law \& Economics. New York: Kluwer.

Sigalas, C. (2015). Empirical investigation of balanced scorecard's theoretical underpinnings. Journal of Accounting and Organizational Change, 11(4): 546-72.

Simon, H. (1951). A formal theory of the employment relationship. Econometrica 19(July): 293$305)$.

Syverson, C. (2011). What determines productivity? Journal of Economic Literature, 49(2): 326-63

Townsend, K., \& Wilkinson, A. (2014). Time to reconnect the silos? Similarities and differences in employment relations and human resources. Human Resource Management Journal, 53(2): 203-10.

Troth, A, \& Guest, D. (2019). The case for psychology in HRM. Human Resource Management Journal, early view.

Walker, G., \& MacDonald, J. (2001). Designing and implementing an HR scorecard. Human Resource Management, 40(4), 365-77.

Wilkinson, A., Wood, G., \& Deeg, R. (2014). The Oxford Handbook of Employment Relations. Oxford: Oxford University Press.

Wright, P., \& McMahan, G. (1992). Theoretical perspectives for strategic human resource management. Journal of Management, 18(2): 295-320.

Wright, P., \& Ulrich, M. (2017). A road well travelled: The past, present, and future journey of strategic human resource management. Annual Review of Organizational Psychology and Organizational Behavior, (4): 45-65.

Zenger, J. \& Folkman, J. (2012). Are you sure you're not a bad boss? Harvard Business Review, (August): 


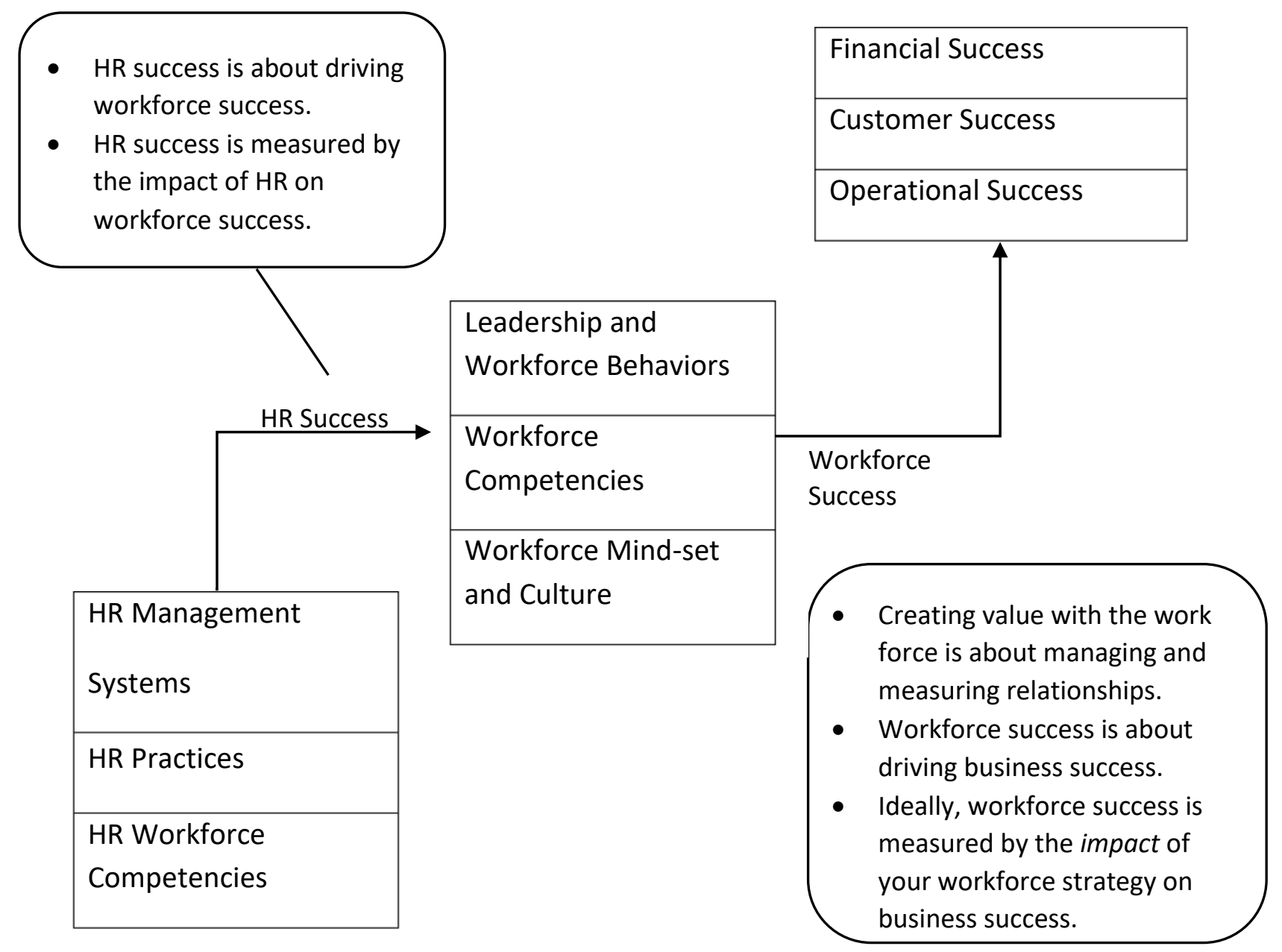

Workforce Success: The Impact of Workforce Strategy on Business Strategy Execution

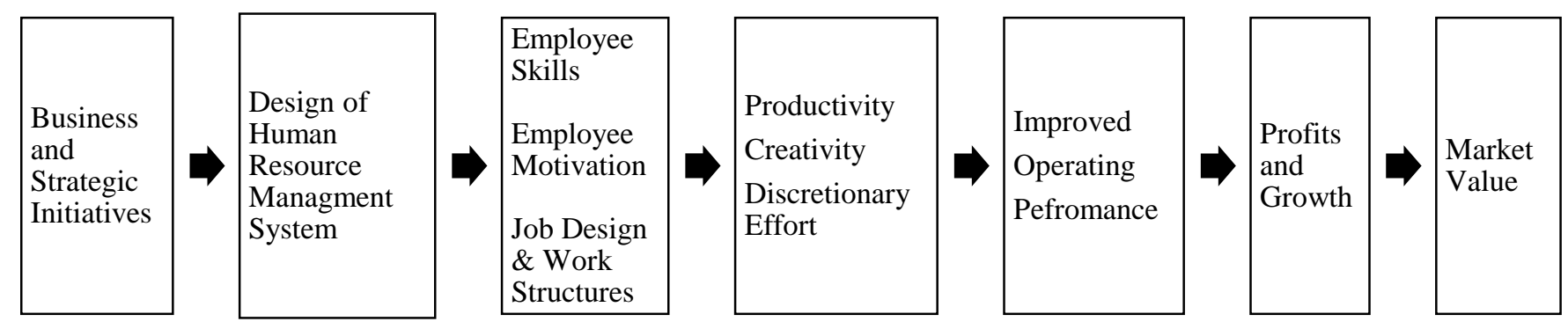

A model of the HR-shareholder value relationship.

Figure 1: HRM Balanced Scorecard Template and B\&H Causal Model 


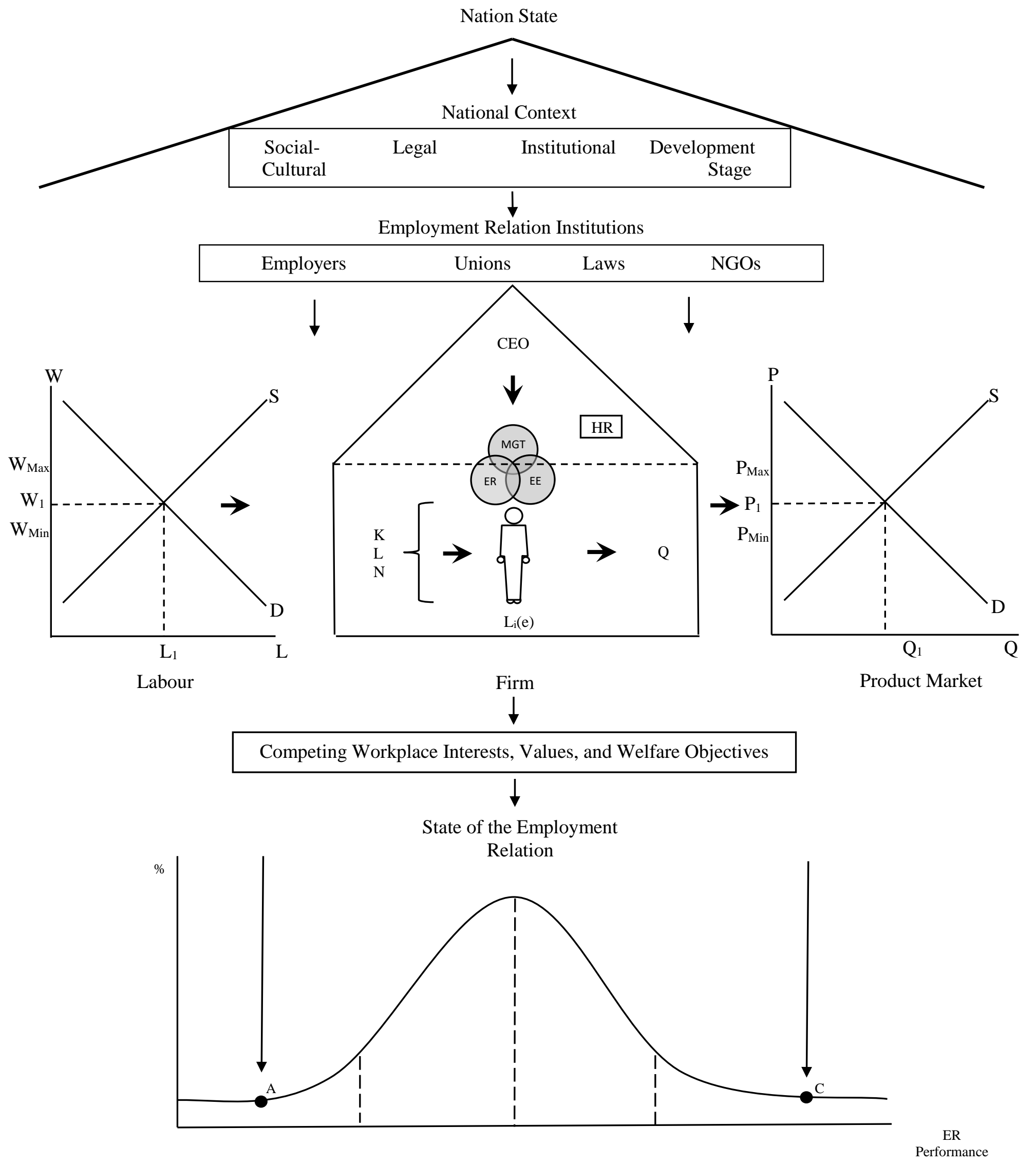

Figure 2. EIR Strategy Map of the Employment Relationship 


\begin{tabular}{|c|c|c|c|c|c|c|c|c|c|c|c|c|}
\hline \multirow[b]{3}{*}{ Section } & \multicolumn{6}{|c|}{ Employer Survey } & \multicolumn{6}{|c|}{ Employee Survey } \\
\hline & \multicolumn{2}{|c|}{ Mean } & \multicolumn{2}{|c|}{ Bottom 20\% } & \multicolumn{2}{|c|}{ Upper 20\% } & \multicolumn{2}{|c|}{ Mean } & \multicolumn{2}{|c|}{ Bottom 20\% } & \multicolumn{2}{|c|}{ Upper $20 \%$} \\
\hline & Score & Grade & Score & Grade & Score & Grade & Score & Grade & Score & Grade & Score & Grade \\
\hline \multicolumn{13}{|l|}{ I. Companies/Workplaces: Performance Outcomes } \\
\hline 1. Management has Optimized Financial Performance & 5.54 & B & 4.31 & C- & 7.00 & $A+$ & N/A & N/A & N/A & N/A & N/A & $\mathrm{N} / \mathrm{A}$ \\
\hline 2. Company/Workplace Financial Performance & 5.62 & B & 4.54 & $\mathrm{C}$ & 6.32 & A- & 5.16 & B- & 3.58 & $\mathrm{D}$ & 6.37 & A- \\
\hline 3. Company/Workplace Competitive Position & 4.41 & C & 3.00 & D- & 5.37 & B & 4.64 & $\mathrm{C}$ & 3.76 & $D+$ & 5.44 & B \\
\hline 4. Change in Employment & 4.86 & $\mathrm{C}+$ & 3.65 & $\mathrm{D}$ & 6.50 & $A$ & 4.13 & C- & 2.54 & $\mathrm{~F}$ & 5.43 & B \\
\hline 5. Company/Workplace Operational Efficiency & 5.53 & B & 4.29 & C- & 7.00 & $A+$ & 4.31 & C- & 1.52 & $\mathrm{~F}$ & 5.79 & $B+$ \\
\hline 6. Employer's Get/Give Value Proposition & 5.67 & $\mathrm{~B}+$ & 4.31 & C- & 7.00 & $A+$ & N/A & N/A & N/A & N/A & $\mathrm{N} / \mathrm{A}$ & $\mathrm{N} / \mathrm{A}$ \\
\hline SECTION SUBTOTAL & 5.27 & B- & 4.01 & C- & 6.53 & A & 4.56 & C & 2.85 & $\mathbf{F}$ & 5.76 & $\mathbf{B}+$ \\
\hline \multicolumn{13}{|l|}{ II. Employees: Satisfaction/Performance Outcomes } \\
\hline 1. Job/Employment Satisfaction & $\mathrm{N} / \mathrm{A}$ & $\mathrm{N} / \mathrm{A}$ & N/A & N/A & N/A & N/A & 4.79 & $\mathrm{C}+$ & 3.23 & D- & 6.43 & A- \\
\hline 2. Great Place to Work & 5.89 & $B+$ & 4.34 & C & 7.00 & $A+$ & 5.03 & B- & 3.22 & D- & 6.43 & A- \\
\hline 3. Pay/Benefits & 5.31 & B- & 3.37 & D & 6.74 & A & 4.58 & C & 2.40 & $\mathrm{~F}$ & 6.45 & A- \\
\hline 4. Employment Security & 5.53 & B & 3.51 & D & 7.00 & $A+$ & 5.06 & B- & 3.27 & D- & 7.00 & $A+$ \\
\hline 5. Friendly/Sociable Workplace Environment & 5.70 & $\mathrm{~B}+$ & 4.49 & C & 7.00 & $A+$ & 5.04 & B- & 3.35 & $\mathrm{D}$ & 6.42 & A- \\
\hline 6. Employee Advancement Opportunities & 5.35 & B & 3.43 & D & 7.00 & $A+$ & 4.12 & C- & 1.43 & $\mathrm{~F}$ & 6.46 & A- \\
\hline 7. Employee's Get/Give Value Proposition & $\mathrm{N} / \mathrm{A}$ & $\mathrm{N} / \mathrm{A}$ & N/A & N/A & N/A & $\mathrm{N} / \mathrm{A}$ & 4.85 & $\mathrm{C}_{+}$ & 3.24 & D- & 6.45 & A- \\
\hline SECTION SUBTOTAL & 5.55 & B & 3.83 & D+ & 6.95 & A & 4.78 & C+ & 2.88 & $\mathbf{F}$ & 6.52 & A \\
\hline \multicolumn{13}{|l|}{ III. Internal Management Capabilities/Performance } \\
\hline 1. Quality of Management Team & 5.75 & $B+$ & 4.29 & C- & 7.00 & $A+$ & 4.63 & C & 2.04 & $\mathrm{~F}$ & 6.43 & A- \\
\hline 2. Quality of People Management & 5.54 & B & 4.31 & C- & 7.00 & $A+$ & 4.31 & C- & 2.09 & $\mathrm{~F}$ & 6.39 & A- \\
\hline 3. Confidence/Trust in Management & 5.66 & B & 4.22 & C- & 7.00 & $A+$ & 4.32 & C- & 1.46 & $\mathrm{~F}$ & 5.99 & $\mathrm{~B}+$ \\
\hline 4. Effectively Deals with Underperformer/Problem Employees & 4.73 & $\mathrm{C}+$ & 1.97 & $\mathrm{~F}$ & 6.43 & A- & 4.24 & C- & 2.09 & $\mathrm{~F}$ & 6.54 & A \\
\hline 5. Value-added from HR function at organization & 5.89 & $\mathrm{~B}+$ & 4.18 & C- & 7.00 & A+ & N/A & N/A & $\mathrm{N} / \mathrm{A}$ & N/A & $\mathrm{N} / \mathrm{A}$ & N/A \\
\hline SECTION SUBTOTAL & 5.52 & B & 3.79 & $\mathrm{D+}$ & 6.89 & A & 4.38 & C & 1.92 & $\mathbf{F}$ & 6.34 & A- \\
\hline \multicolumn{13}{|l|}{ IV. Internal Workforce Capabilities/Performance } \\
\hline 1. Quality of Workforce & 5.78 & $\mathrm{~B}+$ & 4.56 & C & 7.00 & A+ & 5.04 & B- & 3.35 & $\mathrm{D}$ & 6.38 & A- \\
\hline 2. Engagement & 5.63 & B & 4.32 & C- & 7.00 & $A+$ & 4.66 & $\mathrm{C}+$ & 3.30 & D- & 6.35 & A- \\
\hline
\end{tabular}




\begin{tabular}{|c|c|c|c|c|c|c|c|c|c|c|c|c|}
\hline 3. Provided with Good Job Resources & 5.72 & $\mathrm{~B}+$ & 4.31 & C- & 7.00 & $A+$ & 4.77 & $\mathrm{C}+$ & 3.22 & D- & 6.45 & $A-$ \\
\hline 4. Low Employee Turnover & 3.71 & $D+$ & 1.40 & $\mathrm{~F}$ & 6.49 & A- & 4.80 & $\mathrm{C}+$ & 2.16 & $\mathrm{~F}$ & 6.43 & $A-$ \\
\hline 5. Difficult/Expensive to Replace Main Employee Group & 3.50 & $\mathrm{D}$ & 2.08 & $\mathrm{~F}$ & 6.37 & A- & 4.09 & C- & 2.12 & $\mathrm{~F}$ & 6.40 & $A-$ \\
\hline SECTION SUBTOTAL & 4.87 & $\mathrm{C}_{+}$ & 3.33 & D & 6.77 & A & 4.67 & $\mathrm{C}_{+}$ & 2.83 & $\mathbf{F}$ & 6.40 & A- \\
\hline \multicolumn{13}{|l|}{ V. Employer-Employee Relations and Climate } \\
\hline $\begin{array}{l}\text { 1. Employees Treated Fairly/Humanely } \\
\text { 2. Management Receptivity/Interest in Hearing Employees' }\end{array}$ & N/A & $N / A$ & N/A & $\mathrm{N} / \mathrm{A}$ & $\mathrm{N} / \mathrm{A}$ & N/A & 4.90 & $\mathrm{C}+$ & 3.11 & D- & 6.43 & $A-$ \\
\hline Gripes/Problems & 5.42 & B & 3.41 & $\mathrm{D}$ & 7.00 & $A+$ & N/A & $\mathrm{N} / \mathrm{A}$ & $\mathrm{N} / \mathrm{A}$ & $\mathrm{N} / \mathrm{A}$ & N/A & $\mathrm{N} / \mathrm{A}$ \\
\hline 3. Relations between Management and Employees & 5.70 & $\mathrm{~B}+$ & 4.29 & C- & 7.00 & $A+$ & 4.62 & $\mathrm{C}$ & 2.14 & $\mathrm{~F}$ & 6.41 & $A-$ \\
\hline 4. Family/Partnership Feeling & 5.58 & B & 4.19 & C- & 7.00 & $A+$ & 4.30 & C- & 2.05 & $\mathrm{~F}$ & 6.40 & A- \\
\hline 5. Little Conflict/Infighting & 4.03 & C- & 1.44 & $\mathrm{~F}$ & 6.45 & A- & 4.50 & $\mathrm{C}$ & 1.51 & $\mathrm{~F}$ & 5.68 & $\mathrm{~B}+$ \\
\hline 6. Workplace Morale & 5.65 & B & 4.31 & C- & 7.00 & $A+$ & 4.42 & $\mathrm{C}$ & 2.07 & $\mathrm{~F}$ & 6.39 & A- \\
\hline 7. Employees' Connection/Interest with What Mgt. Says/Does & 3.69 & $D+$ & 1.40 & $\mathrm{~F}$ & 6.45 & A- & 3.90 & $\mathrm{D}+$ & 2.12 & $\mathrm{~F}$ & 5.77 & $\mathrm{~B}+$ \\
\hline 8. Employees Collaborate/Cooperate with Managers & 5.74 & $\mathrm{~B}+$ & 4.40 & C & 7.00 & $A+$ & N/A & $\mathrm{N} / \mathrm{A}$ & $\mathrm{N} / \mathrm{A}$ & $\mathrm{N} / \mathrm{A}$ & N/A & $\mathrm{N} / \mathrm{A}$ \\
\hline 9. Good Workplace for Women/Minority/LGBT Employees & N/A & N/A & N/A & $\mathrm{N} / \mathrm{A}$ & $\mathrm{N} / \mathrm{A}$ & N/A & 5.15 & B- & 3.47 & $\mathrm{D}$ & 6.82 & A \\
\hline SECTION SUBTOTAL & 5.12 & B- & 3.35 & D & 6.84 & A & 4.54 & C & 2.35 & $\mathbf{F}$ & 6.27 & A- \\
\hline \multicolumn{13}{|l|}{ VI. Management Style } \\
\hline 1. Management Decisions Match 'Employees are Most Important Asset' & 5.88 & $\mathrm{~B}+$ & 4.24 & C- & 7.00 & $A+$ & 4.56 & $\mathrm{C}$ & 2.04 & $\mathrm{~F}$ & 6.45 & A- \\
\hline 2. Collaborative/Commitment Management Style & 5.13 & B- & 3.18 & D- & 6.35 & A- & 3.84 & $\mathrm{D}+$ & 1.45 & $\mathrm{~F}$ & 5.75 & $\mathrm{~B}+$ \\
\hline 3. Positive Forms of Employee Motivation & 5.30 & B- & 3.51 & $\mathrm{D}$ & 6.33 & A- & 4.28 & $C-$ & 2.14 & $\mathrm{~F}$ & 6.32 & $A-$ \\
\hline SECTION SUBTOTAL & 5.44 & B & 3.64 & D & 6.56 & A & 4.23 & C- & 1.88 & $\mathbf{F}$ & 6.17 & A- \\
\hline \multicolumn{13}{|l|}{ VII. HRM Functional Practices } \\
\hline 1. Company Invests Resources in Selection/Recruitment & 5.46 & B & 3.61 & D & 7.00 & $A+$ & 4.31 & $C-$ & 2.12 & $\mathrm{~F}$ & 6.41 & A- \\
\hline 2. Company Invests in Training/Skill Development & 5.50 & B & 3.48 & $\mathrm{D}$ & 7.00 & $A+$ & 4.31 & C- & 2.10 & $\mathrm{~F}$ & 6.43 & $A-$ \\
\hline 3. Company Invests in Performance Management & 5.53 & B & 3.53 & $\mathrm{D}$ & 7.00 & $A+$ & 4.27 & $c-$ & 2.04 & $\mathrm{~F}$ & 6.41 & A- \\
\hline 4. Significant Part of Pay is Variable and Related to Performance & 5.15 & B- & 3.16 & D- & 7.00 & $A+$ & 3.46 & $\mathrm{D}$ & 1.00 & $\mathrm{~F}$ & 5.86 & $\mathrm{~B}+$ \\
\hline SECTION SUBTOTAL & 5.41 & B & 3.45 & D & 7.00 & A+ & 4.09 & C- & 1.82 & $\mathbf{F}$ & 6.28 & A- \\
\hline \multicolumn{13}{|l|}{ VIII. Employment Practices for Mutualism } \\
\hline 1. Fill Job Openings with People from Inside & 5.37 & B & 3.53 & $\mathrm{D}$ & 7.00 & $A+$ & 4.52 & $\mathrm{C}$ & 2.06 & $\mathrm{~F}$ & 6.44 & A- \\
\hline 2. Work is Done by Employee Teams with some Self-Management Ability & 5.40 & B & 3.45 & $\mathrm{D}$ & 7.00 & $A+$ & 4.44 & $\mathrm{C}$ & 2.03 & $\mathrm{~F}$ & 6.39 & A- \\
\hline 3. Employee Voice/Involvement in Way Work is Done & 5.66 & B & 4.32 & C- & 7.00 & $A+$ & 4.49 & $\mathrm{C}$ & 2.07 & $\mathrm{~F}$ & 6.42 & $A-$ \\
\hline
\end{tabular}




\begin{tabular}{|c|c|c|c|c|c|c|c|c|c|c|c|c|}
\hline 4. Employee Listening and Opinion Methods & 5.10 & B- & 3.20 & D- & 6.40 & A- & 3.92 & $\mathrm{D}+$ & 1.41 & $\mathrm{~F}$ & 6.40 & A- \\
\hline 5. Effective Dispute Resolution & 5.50 & B & 4.34 & C & 7.00 & $A+$ & 4.45 & C & 2.04 & $\mathrm{~F}$ & 6.43 & A- \\
\hline 6. Effective/Extensive Internal Communication & 5.43 & B & 3.47 & $\mathrm{D}$ & 7.00 & $A+$ & 4.31 & C- & 2.03 & $\mathrm{~F}$ & 6.42 & A- \\
\hline SECTION SUBTOTAL & 5.41 & B & 3.72 & $\mathrm{D}+$ & 6.90 & A & 4.35 & C & 1.94 & $\mathbf{F}$ & 6.42 & A- \\
\hline \multicolumn{13}{|l|}{ IX. Community's Performance Outcome } \\
\hline 1. Customer Satisfaction & 5.75 & $\mathrm{~B}+$ & 4.27 & C- & 7.00 & $A+$ & 4.90 & $\mathrm{C}+$ & 3.46 & $\mathrm{D}$ & 6.38 & A- \\
\hline 2. Corporate Social Responsibility & 5.43 & B & 3.19 & D- & 7.00 & $A+$ & 4.56 & C & 3.25 & D- & 6.49 & A- \\
\hline 3. Flexible Work Arrangements & 5.24 & B- & 3.13 & D- & 7.00 & $A+$ & 4.47 & C & 1.96 & $\mathrm{~F}$ & 6.48 & A- \\
\hline 4. Use Few Year-Round Temporary/Project Workers & 3.52 & D & 1.32 & $\mathrm{~F}$ & 6.47 & A- & N/A & $\mathrm{N} / \mathrm{A}$ & $\mathrm{N} / \mathrm{A}$ & N/A & N/A & $\mathrm{N} / \mathrm{A}$ \\
\hline 5. Pay High Enough to Cover Minimum Living Expenses & N/A & N/A & $\mathrm{N} / \mathrm{A}$ & N/A & N/A & N/A & 4.43 & C & 1.43 & $\mathrm{~F}$ & 5.87 & $\mathrm{~B}+$ \\
\hline SECTION SUBTOTAL & 4.98 & $\mathrm{C}+$ & 2.98 & $\mathrm{~F}$ & 6.87 & A & 4.59 & C & 2.53 & $\mathrm{~F}$ & 6.31 & A- \\
\hline X. OVERALL SCORE & 5.28 & B- & 3.58 & D & 6.82 & A & 4.50 & C & 2.38 & $\mathbf{F}$ & 6.30 & A- \\
\hline
\end{tabular}




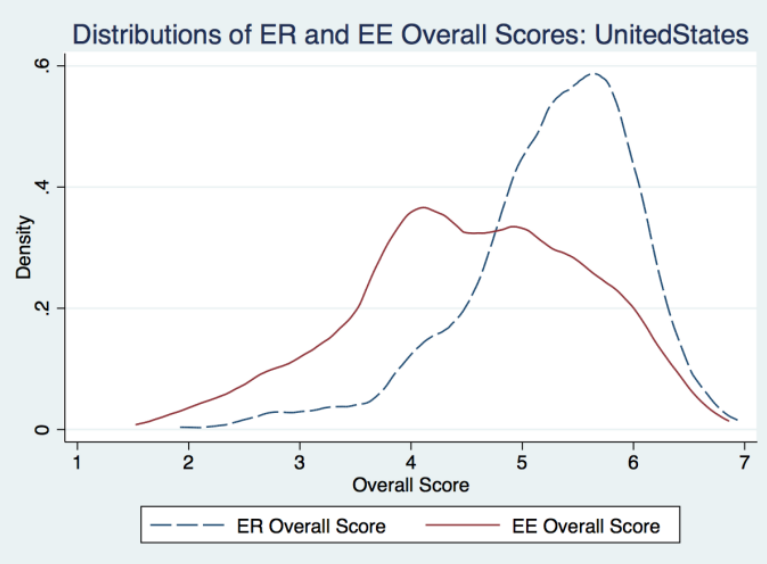

Figure 3. ER Frequency Distributions, Employers and Employees (United States)

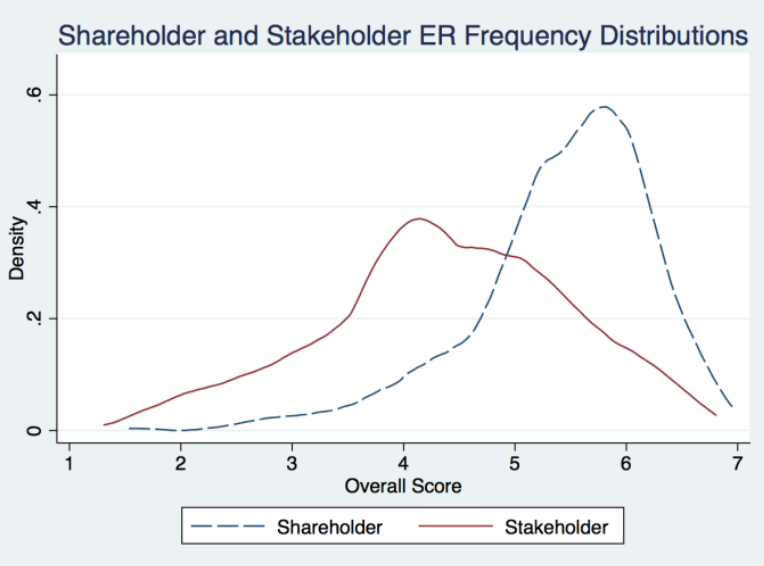

Figure 4. Shareholder and Stakeholder ER Frequency Distributions 


\section{Table 2. Workforce Scorecard: Shareholder and Stakeholder Versions (United States)}

\begin{tabular}{|c|c|c|}
\hline \multirow[b]{2}{*}{ Shareholder Section: Employers } & \multicolumn{2}{|c|}{ Employer Survey } \\
\hline & Score & Grade \\
\hline \multicolumn{3}{|l|}{ Sec 1: Company's Financial Success } \\
\hline Company Financial/Profit Performance & 5.62 & $\mathrm{~B}$ \\
\hline Mgt has Optimized Long-Term Performance of Company & 5.54 & $\mathrm{~B}$ \\
\hline Company's Competitive Position in Product Market & 4.41 & $\mathrm{C}$ \\
\hline \multicolumn{3}{|l|}{ Sec 2: Customer Success } \\
\hline Company has Happy Customers & 5.75 & $\mathrm{~B}+$ \\
\hline \multicolumn{3}{|l|}{ Sec 3: Operational Success } \\
\hline Mgt has Optimized the Company for internal Operational Efficiency & 5.53 & $\mathrm{~B}$ \\
\hline \multicolumn{3}{|l|}{ Sec 4: Workforce Success } \\
\hline $\begin{array}{l}\text { The Workforce Is a Strong Source of Competitive Advantage for the } \\
\text { Company }\end{array}$ & 5.70 & $\mathrm{~B}+$ \\
\hline Mgt has Optimized Performance Contribution of the Workforce & 5.54 & $\mathrm{~B}$ \\
\hline $\begin{array}{l}\text { Management's Actions Match Statement 'Employees are Our Most } \\
\text { Important asset' }\end{array}$ & 5.88 & $\mathrm{~B}+$ \\
\hline $\begin{array}{l}\text { Company has Great Value Proposition in Terms of What it Gets From } \\
\text { Employees Versus What it Gives }\end{array}$ & 5.67 & $\mathrm{~B}+$ \\
\hline \multicolumn{3}{|l|}{ Sec 5: Drivers of Workforce Success } \\
\hline \multicolumn{3}{|l|}{ Leadership and Workforce Behaviors } \\
\hline \multicolumn{3}{|l|}{ Leadership: Front-line Managers } \\
\hline Fully aligned with the Company's Goals and Objectives & 5.77 & $\mathrm{~B}+$ \\
\hline Fully Engaged in their Work & 5.78 & $\mathrm{~B}+$ \\
\hline Very Effectively Collabourate/Cooperate with Employees \& Other Managers & 5.70 & $\mathrm{~B}+$ \\
\hline \multicolumn{3}{|l|}{ Employees } \\
\hline Fully Aligned with the Company's Goals and Objectives & 5.65 & $\mathrm{~B}$ \\
\hline Fully Engaged in their Work & 5.63 & B \\
\hline Very Effectively Collabourate/Cooperate with Other Employees & 5.74 & $\mathrm{~B}+$ \\
\hline
\end{tabular}




\section{Workforce Competencies}

Leadership: Front-Line Managers

Bring Excellent Knowledge, Skills and Abilities to their Jobs $\quad 5.83 \quad \mathrm{~B}+$

Have Few Under-Performers $\quad 3.30$ D-

Very Effective at Employee Side of Leadership and Mgt $\quad 5.68 \quad \mathrm{~B}+$

Employees

First Class Team of Workers $\quad \begin{array}{ll}5.78 & \mathrm{~B}+\end{array}$

Company Good at Providing Employees with Job Resources Needed to

Perform Well

$5.72 \quad B+$

Have Few Under-Performers

$3.27 \quad D-$

\section{Workforce Mind-set and Culture}

Employees' Connection/interest with What Mgt Says/Does

$3.69 \mathrm{D}+$

Company's Workforce has Great Morale

5.65 B

Management Decisions Match 'Employees are Most Important Asset'

$5.88 \quad \mathrm{~B}+$

Mgt Team's Responsiveness on Employees' Dissatisfactions

$5.47 \quad B$

\section{Sec 6: HR Success}

HR Function has Strong Value-added to the Company

$5.89 \quad B+$

\section{Sec 7: Drivers of HR Success}

HR Management Systems

HR Dept Effective at Delivering Traditional HR Services and Programs

$5.95 \quad B+$

\section{HR Workforce Competencies}

Head of HR actively involved with Senior Management on Strategic Business

Decisions and Policy

HR Dept Is an Effective Partner with Line Managers/Supervisors

$5.91 \quad B+$

\section{HR Practices}

High Performance Work Practices - average Score (16 Practices)

Sec 8: Overall Score: Shareholder Card

\subsection{B}

\section{Stakeholder Section: Employees}

\section{Sec 9: Employee Wellbeing Success}

Job/Employment Satisfaction

$4.79 \quad \mathrm{C}+$ 
Great Place to Work

Pay/Benefits

Friendly/Sociable Workplace Environment

\section{Sec 10: Drivers of Employee Wellbeing Success Management Behaviors}

Managers Get Employees Engaged in their Jobs

$4.45 \quad \mathrm{C}$

Managers Get Employees Aligned/Focused on Company's Goals

$4.66 \mathrm{C}$

Managers Empower and Trust Employees to Get their Jobs Done

$4.80 \mathrm{C}+$

Managers are Committed to the Organization's Long-Term Success

\section{Management Competencies}

Quality of Management Team

Quality of People Management

$4.31 \quad \mathrm{C}-$

Confidence/Trust in Management

4.32 C-

Effectively Deals with Underperformer/Problem Employees

4.24 C-

\section{Workforce Mind-set and Culture}

Employees Stay with Company a Long Time

Same Set of Rules and Standards applied to Managers and Employees

Family/Partnership Feeling

Appreciation and Recognition for the Good Job Employees Do

If the Company asks for More From Employees it also Gives More in Return

Workplace Morale

Employees' Connection/interest with What Mgt. Says/Does

Good Workplace for Women/Minority/LGBT Employees

Management Decisions Match 'Employees are Most Important Asset'
$4.80 \mathrm{C}+$

3.59 D

$4.30 \quad$ C-

$3.87 \quad \mathrm{D}+$

$3.65 \mathrm{D}$

$4.42 \mathrm{C}$

$3.90 \mathrm{D}+$

5.15 B-

$4.56 \quad \mathrm{C}$

4.03 C-

\section{Sec 12: Relations}

\section{Relational Behaviors}

Relations Between Management and Employees

Company Fairly Shares Money with Employees

$3.90 \mathrm{D}+$

Management Is Fair and Balanced So Employees Don't Need Outside

Protection and Influence

4.06 C- 
Low Conflict/Infighting

$4.50 \mathrm{C}$

Employees are not Interested in Having Union and Collective Bargaining

4.75

$\mathrm{C}+$

No Discrimination or Favoritism at Work

4.08 C-

Relational Practices

Employee Voice/involvement in Way Work Is Done

$4.49 \quad \mathrm{C}$

Employee Listening and Opinion Methods

$3.92 \mathrm{D}+$

Effective Dispute Resolution

$4.45 \mathrm{C}$

Effective/Extensive Internal Communication

$4.31 \quad \mathrm{C}-$

Collabourative/Commitment Management Style

$3.84 \quad \mathrm{D}+$

Positive Forms of Employee Motivation

4.28 C-

Sec 13: Overall Score: Stakeholder Card

$4.38 \mathrm{C}$

Sec 14: Overall Score: Shareholder + Stakeholder Cards

$5.42(B)+4.38(C)=C+$ 